\title{
Performance evaluation of an animal drawn manure spreader cum cart
}

\author{
S. T. PATIL AND P. A. MUNDE
}

\begin{abstract}
Indian soils are poor in nitrogen. Nearly $1 / 3^{\text {rd }}$ of Indian soils are acidic. Food shortage in 1960s necessitated green revolution, ushering in the use of high dose of chemical fertilizers and poisonous plant protection chemicals adversely affecting the health of the soil. But long term use of these fertilizers causes degradation of soil, compaction and reduces soil fertility. Organic manures when incorporated into the soil it add nutrients it. Application of FYM improves soil fertility. Therefore, there is wide scope to its application. FYM contains almost all the essential nutrient required for soil. The addition of farm yard manure to the field is carried out traditionally. So there is scope of work to distribute the farm yard manure uniformly on the soil surface. By considering these aspects, an animal drawn manure spreader cum cart with electricity generation unit was design and fabricated.The research work and testing was undertaken at the site of the AICRP on UAE CAET, V.N.M.K.V., Parbhani.The developed Manure spreader consist a chassis having two iron wheels, axel assembly, bearing, flat type agitator, peg tooth agitator, body frame for mounting the trapezoidal shaped manure box, hitching system and tool box. The application rate of manure varies from 2.46 to $10.06 \mathrm{t} / \mathrm{ha}$ for varies in opining area of cover $0.04 \mathrm{~m}^{2}$ to $0.16 \mathrm{~m}^{2}$. The co-efficient of variation of uniformity for manure distribution varied from $18-20$ per cent. The designed manure spreader cum cart gave desired manure application rate $\left(9-10 \mathrm{t} / \mathrm{ha}\right.$ ) at an opining area of cover $0.16 \mathrm{~m}^{2}$ at the operational speed of $2.63 \mathrm{~km} / \mathrm{hr}$ and draft required was 637 $\mathrm{N}$. The draft and power requirement of manure spreader were $637 \mathrm{~N}$ and $0.46 \mathrm{~kW}$, respectively within the draft ability limit of pair of bullock. The field capacity and field efficiency of machine were $0.21 \mathrm{ha} / \mathrm{hrand} 84$ per cent at operational speed $2.51 \mathrm{~km} / \mathrm{hr}$. The manure spreader cum cart was used for carting with $500 \mathrm{~kg}$ load on Tar road and Kaccha road by Red Kandhari bullocks. The draft observed for Tar road with no load and $500 \mathrm{~kg}$ load conditions by Red Kandhari bullocks was 37 and $41 \mathrm{~kg}$. respectively. The draft observed on Kaccha road for no load and $500 \mathrm{~kg}$ load conditions was 40 and $48 \mathrm{~kg}$, respectively by Red Kandhari bullocks. Speed observed on Tar road for no load and $500 \mathrm{~kg}$ load conditions by RK bullock was 4.29 and $3.88 \mathrm{~km} / \mathrm{hr}$, respectively. The speed on Kaccha road was 4.04 and $3.48 \mathrm{~km} / \mathrm{hr}$, respectively. Power observed for no load and $500 \mathrm{~kg}$ load conditions was 0.40 and 0.43 , respectively for RK bullock on tar road. And 0.43 and $0.48 \mathrm{Kw}$ for no load and $500 \mathrm{~kg}$ load conditions, respectively on Kaccha road for RK bullock. The increased respiration rate and pulse rate was observed after 2 hrs continuous work on tar and Kaccha road is within the safe limit of fatigue score.
\end{abstract}

KEY WORDS : FYM, Agitator, Manure box, Cart, Spreader, Field efficiency, Application rate, Draft, Speed

How to cite this Article : Patil, S.T. and Munde, P.A.(2017). Performance evaluation of an animal drawn manure spreader cum cart. Engg. \& Tech. in India, 8 (1\&2) : 80-92; DOI : 10.15740/HAS/ETI/8.1\&2/ 80-92. 